DOI : https://doi.org/10.24123/jbt.v4i2.2924

\title{
PENGARUH PERTUMBUHAN PERUSAHAAN, UKURAN PERUSAHAAN, PERENCANAAN PAJAK TERHADAP MANAJEMEN LABA DENGAN GOOD CORPORATE GOVERNANCE SEBAGAI PEMODERASI
}

\author{
Galuh Artika Febriayanti \\ Politeknik Ubaya; 081803893095 \\ Email: galuh.af@staff.ubaya.ac.id
}

\begin{abstract}
The implementation of Good Corporate Governance (GCG) will encourage business people to carry out business practices that prioritize the going concern of the company, the interests of stakeholders, and avoid ways of gaining instant profits that are detrimental to others so as to create fair competition and a conducive business climate. Good Corporate Governance (GCG) implemented by companies in Indonesia is very important to support economic growth and stability. Research on earnings management has been carried out both overseas and domestically. But it was found that there was a research gap in previous studies. This research was conducted because of the gap research phenomenon from previous studies. The object of this research is manufacturing companies listed on the Indonesia Stock Exchange from 2015-2018 with a sample of 57 companies. The results showed that company growth and company size did not have a significant effect on earnings management. While tax planning has a significant influence on earnings management. This research shows that Good Corporate Governance does not moderate the relationship between company size and earnings management. Good Corporate Governance also does not moderate the relationship between tax planning and earnings management.
\end{abstract}

Keywords: Company Growth, Tax Planning, Company Size, Good Corporate Governance, Earnings Management.

\section{Pendahuluan}

Salah satu bentuk tanggung jawab perusahaan kepada stakeholder di akhir periode adalah membuat laporan keuangan. Selain berfungsi sebagai bentuk tanggung jawab, laporan keuangan juga merupakan media komunikasi perusahaan terhadap pihakpihak yang berkepentingan. Salah satu alat ukur yang dapat digunakan untuk mengetahui kinerja perusahaan adalah besarnya angka laba yang diperoleh. Angka laba yang semakin tinggi dari tahun ke tahun dapat diasumsikan bahwa perusahaan mampu mengelola sumber dayanya secara maksimal untuk memperoleh keuntungan (Swingly dan Sukartha, 
2015:48). Laba juga sering digunakan sebagai dasar untuk pembuatan keputusan seperti pemberian bonus dan kompensasi kepada manajer. Oleh karena itu para manajer seringkali berperilaku sesuai dengan bonus yang akan diperoleh. Apabila bonus yang akan diperoleh tergantung pada laba yang dihasilkan maka manajer akan melakukan rekayasa akuntansi dengan meningkatkan laba. Rekayasa akan diatur oleh manajer sehingga tidak melanggar standar akuntansi. Situasi tersebut mendorong manajer untuk melakukan penyimpangan dalam menyajikan dan melaporkan informasi mengenai laba. Selain manajer yang fokus pada laba perusahaan, pihak investor juga sangat tertarik untuk menanamkan modalnya pada perusahaan yang memiliki laba tinggi. Adanya kecenderungan perhatian pada informasi laba ini tentu disadari oleh manajemen, sehingga informasi laba menjadi sasaran utama manajemen untuk direkayasa sesuai dengan kepentingan manajamen. Akibat hal tersebut para pemakai laporan keuangan seperti para stakeholders dan kreditor merasa dirugikan atas tindakan manajemen yang merekayasa laba, dikarenakan tidak mencerminkan keadaan perusahaan yang sesungguhnya. Situasi yang mendorong manajer untuk melakukan penyimpangan pelaporan dan penyajian informasi laba dikenal dengan praktik manajemen laba (earnings management).

Manajemen laba dapat dibagi menjadi dua arah yaitu earnings management up dan earnings management down. Arah earnings management up ialah manajemen laba yang dilakukan dengan tujuan untuk menaikkan laba. Earnings management up memberikan kesan kepada pemakai laporan keuangan bahwa perusahaan dapat menghasikan laba yang lebih besar dari tahun sebelumnya atau menutupi penurunan laba yang dihasilkan. Arah earnings management down merupakan manajemen laba yang dilakukan dengan tujuan untuk menurunkan atau meratakan laba. Earnings management down dilakukan dengan tujuan untuk menghindari kewajiban-kewajiban tertentu seperti pembayaran pajak dan dividen. Selain itu, manajemen laba dengan arah turun biasanya dilakukan untuk menghindari perhatian yang berlebih pada perusahaan yang telah memiliki nama besar dan mempercantik rasio keuangan seperti menstabilkan profitabilitas perusahaan dengan perataan laba (Wibisana dan Ratnaningsih, 2014:2). Ada beberapa faktor yang mempengaruhi manajemen laba di perusahaan. Penelitian ini mengambil pertumbuhan perusahaan, ukuran perusahaan, perencanaan pajak sebagai variabel yang dianggap memiliki pengaruh terhadap manajemen laba.

Berdasarkan tujuannya penelitian ini merupakan explanatory research yang bertujuan menguji hipotesis bagaimana pengaruh pertumbuhan perusahaan, ukuran perusahaan, perencanaan pajak terhadap manajemen laba dengan Good Corporate Governance (GCG) sebagai variabel pemoderasi terhadap ukuran perusahaan dan perencanaan pajak.

\section{Landasan Teori}

\section{Teori Keagenan}

Timbulnya praktek manajemen laba dapat dijelaskan dengan teori agensi. Teori keagenan membahas tentang adanya hubungan keagenan antara prinsipal dan agen. Permasalahan manajemen laba merupakan masalah keagenan yang seringkali dipicu oleh adanya pemisahan peran atau perbedaan kepentingan antara pemilik (pemegang saham) dengan pengelola perusahaan (manajemen). Konsep agency theory menurut Siagian (2011:10) "adalah hubungan atau kontrak antara prinsipal dan agen". Prinsipal mempekerjakan agen melakukan tugas untuk kepentingan prinsipal, termasuk pendelegasian otorisasi pengambilan keputusan dari prinsipal kepada agen. Agency conflict merupakan pemisahan yang terjadi antara kepemilikan dan pengelolaan perusahaan. Teori keagenan merupakan teori yang mendasari praktik bisnis perusahaan dimana yang mengelola sebuah perusahaan tidak dilakukan oleh pemiliknya melainkan 
diserahkan kepada pihak lain, hal tersebut akan menimbulkan potensi konflik antara pemilik dengan pengelola atau sering disebut agency problem. Dalam teori agensi, hubungan keagenan muncul karena adanya suatu kontrak dimana satu atau lebih orang (principle) memerintah orang lain (agent) untuk melakukan jasa atas nama pemilik serta memberikan beberapa wewenang pengambilan keputusan kepada agen (Kusumawati, 2019:27).

Teori keagenan memiliki asumsi bahwa masing-masing individu memiliki motivasi terhadap kesejahteraan dan kepentingan dirinya sendiri. Pihak prinsipal termotivasi mengadakan kontrak untuk mensejahterakan dirinya melalui pembagian dividen atau kenaikan harga saham perusahaan sedang agen termotivasi untuk meningkatkan kesejahteraan melalui peningkatan kompensasi. Konflik kepentingan semakin meningkat ketika prinsipal tidak memiliki informasi yang cukup tentang kinerja agen karena ketidakmampuan prinsipal memonitor aktivitas agen dalam perusahaan. Sedangkan agen memiliki lebih banyak informasi mengenai kapasitas diri, lingkungan kerja, dan perusahaan secara keseluruhan. Hal tersebut mengakibatkan adanya ketidakseimbangan informasi yang dimiliki prinsipal dan agen yang dikenal dengan asimetri informasi.

\section{Manajemen laba (Earnings Management)}

Manajemen laba dapat didefinisikan sebagai "suatu tindakan yang dilakukan melalui pemilihan kebijakan akuntansi untuk memperoleh tujuan tertentu misalnya untuk meningkatkan nilai perusahaan atau untuk kepentingan pribadi manajemen perusahaan" (Scott, 2011:369). Aditama dan Anna Purwaningsih (2014:36) mendefinisikan sebagai berikut:

Manajemen laba merupakan aktivitas manajerial untuk "mempengaruhi" laporan keuangan baik dengan cara memanipulasi data atau informasi keuangan perusahaan maupun dengan cara pemilihan metode akuntansi yang diterima dalam prinsip akuntansi berterima umum, yang pada akhirnya bertujuan untuk memperoleh keuntungan perusahaan.

Perusahaan dapat menyembunyikan kecurangan dengan memanfaatkan berbagai metode dan prosedur yang terdapat dalam standar akuntansi, sehingga standar akuntansi seolaholah mengakomodasi dan memberi kesempatan perusahaan untuk mengatur dan mengelola laba perusahaan (Gustina dan Lince Bolutodung, 2017:199).

\section{Pertumbuhan perusahaan terhadap manajemen laba}

Pertumbuhan perusahaan merupakan nilai yang menunjukkan besar kecilnya perusahaan. Investor dalam menanam modal yang ditanamkan artinya memperoleh hasil yang menguntungkan. Namun perusahaan besar cenderung menjaga laporan posisi keuangannya dalam keadaan tertentu sehingga kinerjanya tidak terlalu baik, dengan menyajikan laba yang lebih rendah dari nilai yang sebenarnya terutama selama periode kemakmuran tinggi. Perusahaan yang memperoleh pertumbuhan pendapatan yang rendah memiliki kecenderungan untuk memanipulasi laba. Fricilia dan Hendro (2015:89) meneliti faktor-faktor yang mempengaruhi praktik manajemen laba pada industri perbankan di Indonesia. Salah satu variabel independen yang diteliti adalah growth perusahaan. Growth yang diukur dengan pendapatan bunga dan operasional dinyatakan mempunyai pengaruh signifikan terhadap manajemen laba. Hal ini disebabkan untuk meningkatkan pertumbuhan kinerja di mata publik perusahaan cenderung melakukan manipulasi laporan keuangan.

Purbandari dan Intan (2018:62) telah melakukan pengujian untuk membuktikan analisis faktor fundamental terhadap manajemen laba pada perusahaan yang listed di Bursa Efek Indonesia. Variabel independen yang diteliti dalam penelitian tersebut adalah kepemilikan institusional, ukuran perusahaan KAP big 4 dan KAP non big 4, dewan komisaris independen, komite audit, dewan direksi, leverage, persentase saham yang ditawarkan ke publik saat IPO dan perusahaan yang bertumbuh. Terkait dengan 
perusahaan bertumbuh proksi yang digunakan dalam penelitian tersebut adalah growth yang diperoleh berdasarkan perbandingan antara total aset periode sekarang (total aset $t$ ) minus periode sebelumnya (total aset $\mathrm{t}-1$ ) terhadap total aset periode sebelumnya. Hasil pengujian terhadap variabel perusahaan bertumbuh membuktikan bahwa perusahaan yang bertumbuh berpengaruh terhadap manajemen laba. Dari beberapa penelitian tersebut terdapat hasil yang tidak konsisten terkait pengaruh pertumbuhan perusahaan terhadap manajemen laba sehingga penelitian ini menguji kembali pengaruh pertumbuhan perusahaan terhadap manajemen laba.

Berdasarkan landasan teori di atas maka hipotesis penelitiannya adalah:

$\mathrm{H}_{1} \quad$ : Terdapat pengaruh antara pertumbuhan perusahaan dengan manajemen laba.

\section{Ukuran perusahaan terhadap manajemen laba}

Ukuran perusahaan memegang peranan penting dalam perusahaan yang melakukan praktik manajemen laba. Ukuran perusahaan yang kecil dianggap lebih banyak melakukan praktik manajemen laba daripada perusahaan besar. Hal ini disebabkan karena perusahaan kecil cenderung ingin memperlihatkan kondisi perusahaan yang selalu berkinerja baik agar investor menanamkan modalnya pada perusahaan tersebut. Berbeda dengan perusahaan kecil, perusahaan besar biasanya akan lebih berhatihati dalam melakukan pelaporan keuangan, karena perusahaan yang besar lebih diperhatikan oleh masyarakat.

Penelitian yang dilakukan Makaombohe, Sifrid, dan Victorina (2014:658) terkait pengaruh ukuran perusahaan terhadap manajemen laba menghasilkan bukti empiris ukuran perusahaan berpengaruh signifikan negatif terhadap manajemen laba. Hasil penelitian ini mendukung pandangan bahwa ukuran perusahaan berpengaruh negatif terhadap manajemen laba artinya semakin besar ukuran perusahaan maka perilaku manajemen laba akan semakin menurun, sebab perusahaan yang lebih besar kurang memiliki dorongan untuk melakukan manajemen laba dibandingkan perusahaanperusahaan kecil dan karena perusahaan besar dipandang lebih kritis oleh pemegang saham dan pihak luar. Aprina dan Khairunnisa (2015:3257) melakukan penelitian empiris untuk membuktikan pengaruh ukuran perusahaan, profitabilitas, dan kompensasi bonus terhadap manajemen laba. Pengujian dilakukan baik secara parsial maupun simultan untuk melihat pengaruh variabel independen terhadap variabel dependen. Hasil penelitian membuktikan secara simultan ukuran perusahaan, profitabilitas, dan kompensasi bonus berpengaruh signifikan secara bersama-sama terhadap manajemen laba pada perusahaan retail yang terdaftar di BEI tahun 2012-2014. Secara parsial kompensasi bonus tidak memiliki pengaruh signifikan terhadap manajemen laba. Landasan teori di atas digunakan untuk membentuk hipotesis yang kedua dari penelitian ini, yaitu:

$\mathrm{H}_{2} \quad$ : Terdapat pengaruh antara ukuran perusahaan dengan manajemen laba.

\section{Perencanaan pajak terhadap manajemen laba}

Menurut Suandy (2014:6), dalam bukunya yang berjudul perencanaan pajak menyatakan bahwa:

Perencanaan pajak adalah langkah awal dalam manajemen pajak. Pada tahap ini dilakukan pengumpulan dan penelitian terhadap peraturan perpajakan agar dapat diseleksi jenis tindakan penghematan pajak yang akan dilakukan. Pada umumnya penekanan perencanaan pajak) adalah untuk meminimumkan kewajiban pajak.

Penelitian yang dilakukan Achyani dan Susi menunjukkan bahwa perencanaan pajak, beban pajak tangguhan, aset pajak tangguhan, dan kepemilikan manajerial tidak berpengaruh terhadap manajemen laba. Hal ini berarti bahwa perencanaan pajak merupakan keinginan dari pihak investor yang menginginkan biaya yang dikeluarkan perusahaan kecil, sehingga dapat memperoleh dividen yang lebih tinggi, bukan merupakan keinginan pihak manajemen. Hasil penelitian ini juga menunjukkan bahwa free cash flow berpengaruh terhadap manajemen laba. Hal ini berarti bahwa adanya free 
cash flow dapat dimanfaatkan manajemen untuk melakukan manajemen laba. Manajemen mengupayakan free cash flow yang tinggi dengan tujuan untuk memperlihatkan kinerja perusahaan yang baik. Selain itu tersedianya free cash flow dapat dimanfaatkan untuk kepentingan manajemen sendiri (Achyani dan Susi, 2019:86). Khotimah (2014:176) melakukan penelitian untuk menguji secara empiris pengaruh perencanaan pajak terhadap manajemen laba. Hasil pengujian empiris membuktikan bahwa perencanaan pajak yang diproksikan dengan tarif pajak efektif lebih berpengaruh signifikan dari pada perencanaan pajak yang diproksikan dengan beban pajak tangguhan. Beban pajak tangguhan tidak berpengaruh signifikan terhadap manajemen laba. Hasil ini mendukung teori equity view yang menyatakan bahwa pajak tangguhan tidak memiliki nilai relevansi karena ketidakpastian hal yang berhubungan dengan arus kas. Secara umum hasil penelitian menunjukkan bahwa perencanaan pajak berpengaruh terhadap besaran discretionary current accrual. Berdasarkan landasan teori di atas maka hipotesis penelitiannya adalah:

$\mathrm{H}_{3} \quad$ : Terdapat pengaruh antara perencanaan pajak dengan manajemen laba.

\section{Good corporate governance (GCG)}

Good Corporate Governance (GCG) adalah rangkaian proses, kebiasaan, kebijakan, aturan dan institusi yang mempengaruhi pengarahan, pengelolaan, serta pengontrolan suatu perusahaan atau korporasi. Good Corporate Governance (GCG) juga mencakup hubungan antara para pemangku kepentingan (stakeholder) yang terlibat serta tujuan pengelolaan perusahaan. Pihak-pihak utama dalam tata kelola perusahaan adalah pemegang saham, manajemen dan dewan direksi (Pertiwi dan Ferry, 2012:120). Inti dari kebijakan t Good Corporate Governance (GCG) adalah agar pihak-pihak yang berperan dalam menjalankan perusahaan memahami dan menjalankan fungsi dan peran sesuai wewenang dan tanggung jawab. Pihak yang berperan meliputi pemegang saham, dewan komisaris, komite, direksi, pimpinan unit dan karyawan. Beberapa penelitian terkait Good Corporate Governance (GCG) terhadap manajemen laba telah banyak dilakukan baik sebagai variabel independen maupun moderasi. Yudiastuti dan I Wayan (2018:152) melakukan penelitian Good Corporate Governance (GCG) memoderasi pengaruh leverage terhadap manajemen laba. Good Corporate Governance (GCG) sebagai variabel moderasi diukur dengan skor Corporate Governance Perception Index (CGPI) perusahaan dalam penilaian yang dilakukan The Indonesian Institute for Corporate Governance (IICG) yang dipublikasikan oleh majalah SWA. Hasil penelitian menunjukkan Leverage dengan menggunakan Debt to Equity Ratio (DER) tidak berpengaruh terhadap manajemen laba. Tinggi rendahnya tingkat leverage suatu perusahaan tidak mempngaruhi praktik manajemen laba yang akan dilakukan perusahaan.

Lestari dan Sugeng (2013:501) melakukan penelitian untuk melihat pengaruh Earnings Management terhadap nilai perusahaan dimoderasi dengan praktik Good Corporate Governance. Berdasarkan hasil penelitian didapatkan kesimpulan bahwa mananajemen laba memiliki pengaruh negatif yang signifikan terhadap nilai perusahaan. Perusahaan yang melakukan manajemen laba yang tinggi akan dapat membuat nilai perusahaan menjadi lebih rendah. Hasil pengujian diperoleh bahwa keempat variabel corporate governance secara terpisah maupun secara keseluruhan tidak memiliki pengaruh yang signifikan terhadap nilai perusahaan. Hasil penelitian mendapatkan bahwa variabel corporate governance tidak keseluruhan berpengaruh signifikan dalam memoderasi pengaruh manajemen laba terhadap nilai perusahaan.

Manajemen laba merupakan tindakan manajer dalam memanipulasi laba perusahaan dengan pemanfaatan dari kebijakan akuntansi tertentu. Salah satu bentuk pemanfaatan dari kebijakan akuntansi adalah melakukan perencanaan pajak. Good Corporate Governance (GCG) diduga memoderasi antara perencanaan pajak dan manajemen laba. Apabila perusahaan sudah menerapkan Good Corporate Governance (GCG) maka bisa memperlemah pengaruh praktik perencanaan pajak terhadap manajemen laba. Begitu pula dengan ukuran perusahaan. Perusahaan kecil maupun besar cenderung melakukan manajemen laba untuk menarik investor sehingga apabila 
perusahaan telah menerapkan Good Corporate Governance (GCG) pengaruh manajemen laba bisa berkurang.

Berdasarkan landasan teori di atas maka hipotesis penelitiannya adalah:

$\mathrm{H}_{4} \quad$ : Good Corporate Governance (GCG) mampu memoderasi antara ukuran perusahaan dengan manajemen laba.

$\mathrm{H}_{5} \quad$ : Good Corporate Governance (GCG) mampu memoderasi antara perencanaan pajak dengan manajemen laba.HASIL PENELITIAN

\section{Definisi Operasional Variabel}

Variabel dalam penelitian ini dikelompokkan menjadi 2 yaitu:

1. Variabel Dependen

Variabel dependen dalam penelitian ini adalah Manajemen Laba

Manajemen laba diproksikan dengan discretionary accruals menggunakan model modified Jones. Variabel ini diukur menggunakan skala nominal, di mana untuk mendapatkan nilai discretionary accruals peneliti perlu mengestimasi variabel ini dengan menggunakan persamaan regresi ordinary least square. Peneliti tidak menggunakan nondiscretionary accruals karena diasumsikan nilai dapat berubah sehingga membuat perhitungan manajemen laba menjadi bias. Langkah-langkah menghitung discretionary accruals:

1. Menghitung nilai total akrual.

$\mathrm{TACt}=\mathrm{Nit}-\mathrm{CFOt}$

Keterangan:

TACt : Total akrual perusahaan i pada tahun ke $\mathrm{t}$

Nit $\quad$ : Laba bersih setelah pajak perusahaan i pada tahun ke $\mathrm{t}($ EBIT)

CFOt : Arus kas operasi perusahaan I pada tahun ke $\mathrm{t}$

2. Menghitung nilai total akrual yang diestimasi dengan persamaan regresi OLS.

$\mathrm{TAC}_{\mathrm{it}} / \mathrm{TA}_{\mathrm{it}}-1=\beta 1\left(1 / \mathrm{TA}_{\mathrm{it}}-1\right)+\beta 2\left(\Delta \mathrm{REV}_{\mathrm{it}} / \mathrm{TA}_{\mathrm{it}}-1\right)+\beta 3\left(\mathrm{PPE}_{\mathrm{it}} / \mathrm{TA}_{\mathrm{it}}-1\right)+$ $\varepsilon_{\mathrm{it}}$

Keterangan:

TACt : Total akrual perusahaan i pada tahun ke $\mathrm{t}$

$\mathrm{TA}_{\mathrm{it}}-1 \quad:$ Total assets perusahaan pada akhir tahun $\mathrm{t}-1$

$\triangle \mathrm{REV}_{\text {it }} \quad:$ Perubahaan total pendapatan pada tahun $\mathrm{t}$

$\mathrm{PPE}_{\mathrm{it}} \quad$ : Property, Plant dan equipment perusahaan pada tahun $\mathrm{t}$

$\varepsilon_{\mathrm{it}} \quad:$ error term

3. Menghitung nondiscretionary accruals (NDA).

$\mathrm{NDA}_{\mathrm{it}}=\beta 1\left(1 / \mathrm{TA}_{\mathrm{it}}-1\right)+\beta 2\left[\left(\Delta \mathrm{REV}_{\mathrm{it}}-\Delta \mathrm{REC}_{\mathrm{it}}\right) / \mathrm{TA}_{\mathrm{it}}-1\right]+\beta 3\left(\mathrm{PPE}_{\mathrm{it}} / \mathrm{TA}_{\mathrm{it}}{ }^{-}\right.$ 1) $+\varepsilon_{\mathrm{it}}$

Keterangan:

$\begin{array}{ll}\mathrm{NDA}_{\text {it }} & : \text { Nondiscretionary accruals perusahaan i pada tahun } \mathrm{t} \\ \mathrm{TA}_{\mathrm{it}}-1 & : \text { Total Assets perusahan pada akhir tahun } \mathrm{t}-1 \\ \Delta \mathrm{REC}_{\mathrm{it}} & : \text { Perubahaan piutang usaha perusahaan pada tahun } \mathrm{t} \\ \mathrm{PPE}_{\mathrm{it}} & : \text { Property, Plant dan equipment perusahaan } \\ & : \text { pada tahun } \mathrm{t} \\ \varepsilon_{\mathrm{it}} & : \text { error term }\end{array}$


Menghitung discretionary accruals (DACC)

$$
\text { DACCit }=\left(\frac{\text { TACt }}{\text { TAit }-1}\right)-\text { NDACCit }
$$

Keterangan:

$\begin{array}{lll}\text { DACC }_{\text {it }} & : \text { Discretionary accruals perusahaan i pada tahun ke t } \\ \text { TAC }_{\mathrm{t}} & : \text { Total akrual perusahaan i pada tahun ke } \mathrm{t} \\ \mathrm{TA}_{\mathrm{it}}-1 & : \text { Total assets perusahaan pada akhir tahun } \mathrm{t}-1 \\ \mathrm{NDACC}_{\mathrm{it}} & : \text { Nondiscretionary accruals perusahaan i pada tahun } \mathrm{t}\end{array}$

2. Variabel Independen.

Variabel Independen dalam penelitian ini adalah:

\section{Pertumbuhan Perusahaan}

Pertumbuhan perusahaan diproksikan dengan aset growth yang diperoleh berdasarkan perbandingan antara total aset periode sekarang (total aset $t$ ) minus periode sebelumnya (total aset $\mathrm{t}-1$ ).

\section{Ukuran Perusahaan}

Ukuran perusahaan diukur menggunakan total aset dan ditransformasikan dalam logaritma karena total aset nilainya relatif lebih besar. Proksi ukuran perusahaan dalam penelitian ini adalah total aset, hal tersebut dikarenakan total aset dinilai lebih stabil daripada proksi lain yang digunakan dalam mengukur ukuran perusahaan (Kusumawati, 2019:31).

\section{Perencanaan Pajak}

Dalam penelitian ini tax planning (perencanaan pajak) diukur dengan tax retention rate (tingkat retensi pajak) dengan rumus (Achyani dan Susi, 2019:81):

$$
\mathrm{TRR}_{\mathrm{it}}=\frac{\text { Net Income }_{\mathrm{it}}}{{\text { Pretax Income }(\mathrm{EBIT})_{\mathrm{it}}}}
$$

Keterangan:

$\mathrm{TRR}_{\mathrm{it}}$

Net Income it $_{\text {Preter }}$ Pretax Income $(\mathrm{EBIT})_{\mathrm{it}}$
$=$ Tax Retention Rate (tingkat retensi pajak) perusahaan i pada tahun $\mathrm{t}$.

$=$ laba bersih perusahaan i pada tahun $\mathrm{t}$.

$=$ laba sebelum pajak perusahaan i pada tahun t.

TRR yang tinggi maka perencanaan pajak juga tinggi. Hal tersebut berarti bahwa TRR yang tinggi menunjukkan bahwa perencanaan pajak yang dilakukan perusahaan semakin efektif. Sebaliknya apabila TRR rendah maka perencanaan pajak perusahaan menjadi kurang efektif (Wardani dan Desifa, 2018:16)

Good Corporate Governance (GCG)

Good Corporate Governance (GCG) dalam penelitian ini diukur dengan kepemilikan manajerial, kepemilikan institusional, dan proporsi dewan komisaris independen (Amperaningrum dan Intan Komala, 2013:298)

$\%$ Kepemilikan manajerial jumlah saham pihak manajer 
modal saham yang beredar

$\begin{array}{ll}\text { \% Dewan Komisaris Independen }= & \frac{\begin{array}{l}\text { jumlah anggota dewan komisaris } \\ \text { independen }\end{array}}{\text { jumlah anggota dewan komisaris }} \\ \% \text { Kepemilikan institusional }= & \frac{\text { jumlah saham pihak institusi }}{\text { modal saham yang beredar }}\end{array}$

\section{Deskripsi variabel penelitian}

Untuk mendapatkan gambaran secara umum tentang data pertumbuhan perusahaan, ukuran perusahaan, perencanaan pajak, good corporate governance dan manajemen laba tersebut dianalisis secara deskriptif guna mengetahui skor minimum maupun maksimum dan untuk mendapatkan nilai kecenderungan sentral (mean), dan standar deviasi. Deskripsi data yang diperoleh dari data penelitian pada masing-masing variabel sebagaimana dalam tabel berikut :

Tabel 1

\section{Deskriptif Variabel Penelitian}

Descriptive Statistics

\begin{tabular}{|l|r|r|r|r|r|}
\hline & $\mathrm{N}$ & \multicolumn{1}{|c|}{ Minimum } & \multicolumn{1}{c|}{ Maximum } & \multicolumn{1}{c|}{ Mean } & \multicolumn{1}{c|}{ Std. Dev iation } \\
\hline Pertumbuhan Persh & 56 & 136618855,00 & 51155890227 & 5770336607,7 & 11018967050 \\
Ukuran Persh & 56 & $-1286904000,00$ & 11494133456 & 618330992,50 & 1903947642,2 \\
Perencanaan Pajak & 56 &,- 54 & 1,99 &, 7570 &, 39851 \\
Kepemilikan Manajerial & 56 &, 00 & 37,32 & 6,6401 & 12,63889 \\
Dewan Komisaris & 56 &, 00 & 60,00 & 30,7292 & 14,96641 \\
Kepemilikan Institusi & 56 &, 96 & 113,16 & 55,6506 & 31,57947 \\
Manajemen Laba & 56 &,- 19 & 76,38 & 1,5777 & 10,18788 \\
Valid N (listwise) & 56 & & & & \\
\hline
\end{tabular}

Sumber : data diolah, 2020

\section{Pembuatan model struktural}

Model struktural dibuat dengan menggabungkan seluruh variabel laten berdasarkan teori substansi. Variabel laten dibagi menjadi dua macam, yakni variabel endogen dan eksogen. Variabel eksogen merupakan variabel yang nilainya tidak dipengaruhi oleh variabel lain, oleh karena itu variabel eksogen juga disebut dengan variabel independen. Variabel endogen merupakan yang nilainya dipengaruhi oleh variabel lain di dalam model. Pada model struktural yang dapat dilihat pada gambar 1 semua variabel laten merupakan variabel eksogen kecuali $\mathrm{Z}$ dan $\mathrm{Y}$. Variabel $\mathrm{Z}$ dan $\mathrm{Y}$ merupakan variabel endogen. 


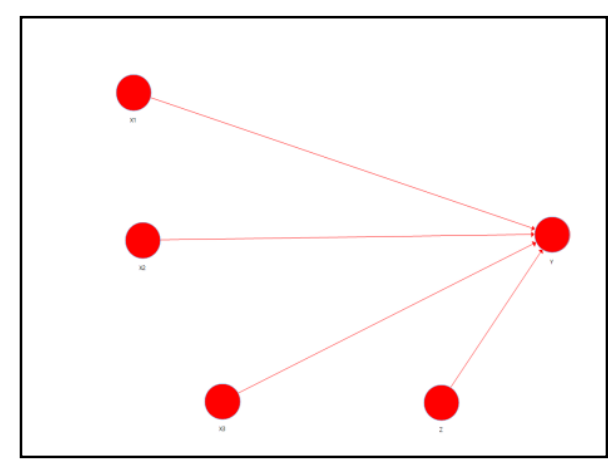

Gambar 1

Model Struktural

Sumber: output model pengukuran dari perangkat lunak SmartPLS

Keterangan :

a. X1 : Pertumbuhan perusahaan

b. X2 : Ukuran perusahaan

c. $\mathrm{X} 3$ : Perencanaan pajak

d. Z : Good Corporate Governance

e. Y : Manajemen laba

\section{Pembuatan model struktural}

Model struktural dibentuk dengan cara menghubungkan semua variabel manifest atau indikator dengan variabel latennya. Satu variabel laten setidak-tidaknya harus memiliki satu variabel manifest. Berikut gambar model pengukuran struktural.

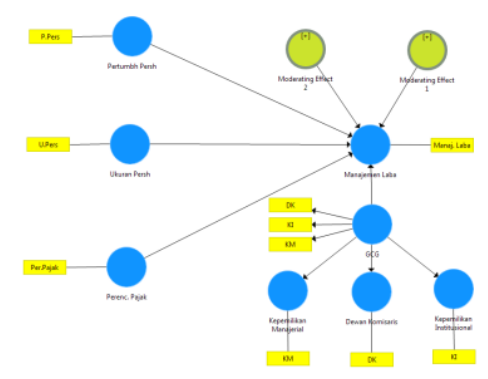

Gambar 2

Model Struktural

Sumber: output model struktural dari perangkat lunak SmartPLS

\section{Analisis Model Pengukuran}

Analisis model pengukuran berfungsi untuk memastikan apakah indikatorindikator yang digunakan dalam mengukur variabel laten reliabel dan valid. Setelah model pengukuran selesai dibuat seperti yang terlihat pada gambar diatas, maka model siap diestimasi dengan menggunakan algoritma PLS yang sudah tersedia pada perangkat lunak SmartPLS. Dalam menggunakan algoritma PLS ada beberapa variabel yang harus ditentukan nilainya pada pengaturan, antara lain initial weight menggunakan nilai 1 untuk seluruh variabel lain, sedangkan pengukuran yang dilakukan dengan Skema pembobotan path menggunakan nilai 300. 


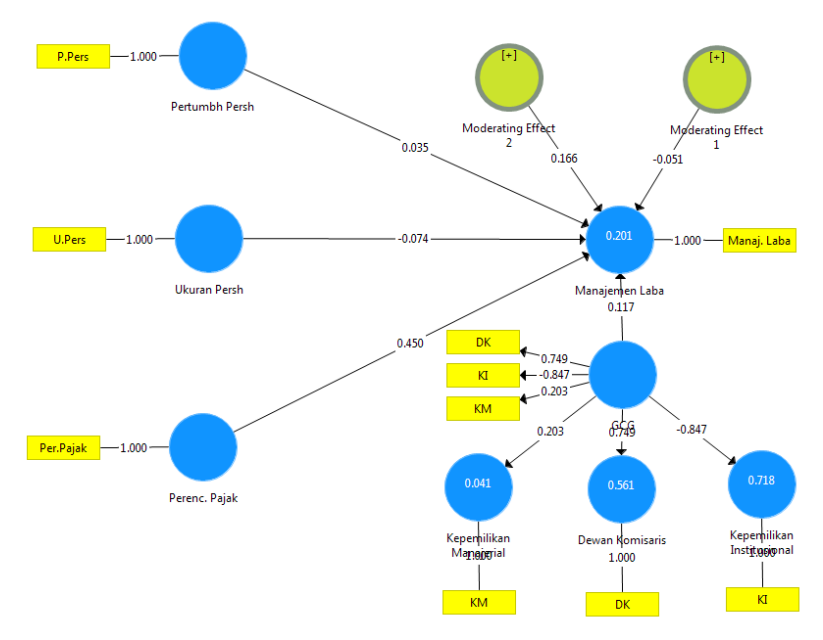

\section{Gambar 3 \\ Path Coefficients Algoritma PLS}

Sumber:output model pengukuran dari perangkat lunak SmartPLS

1) Reliabilitas Indikator

Dalam menggunakan SEM-PLS perlu dilakukan pemeriksaan terhadap reliabilitas indikator-indikator yang digunakan sebagai alat ukur variabel laten. Reliabilitas suatu indikator dapat diterima apabila memiliki nilai reliabilitas indikator $\geq 0,7$ (Hulland, 1999:201), sedangkan Chin yang yang dikutip oleh Imam Ghozali (2014:17-19), nilai outer loading > 0,6 sudah dianggap cukup. Nilai reliabilitas dari setiap indikator dapat dihitung dengan cara mengkuadratkan nilai outer loadingyang dihasilkan oleh setiap indikator setelah menjalankan algoritma PLS menggunakan perangkat lunak SmartPLS.

Tabel 2

Hasil Pemeriksaan Reliabilitas Indikator

\begin{tabular}{|c|c|c|c|c|}
\hline Variabel Laten & Indikator & Outer Loading & $\begin{array}{c}\text { Nilai Reliabilitas } \\
\text { Indikator }\end{array}$ & Keterangan \\
\hline $\begin{array}{c}\text { Pertumbuhan } \\
\text { persh }\end{array}$ & & 1,000 & 0,6 & Reliabel \\
\hline Ukuran persh & & 1,000 & 0,6 & Reliabel \\
\hline Perencana pajak & & 1,000 & 0,6 & Reliabel \\
\hline GCG & KM & 0,203 & 0,6 & Tidak reliabel \\
\hline & DK & 0,749 & 0,6 & Reliabel \\
\hline Manajemen Laba & KI & 0,847 & 0,6 & Reliabel \\
\hline
\end{tabular}

Sumber : Pengolahan data dengan perangkat lunak SmartPLS

2) Reliabilitas Konsistensi Internal

Pengukuran reliabilitas konsistensi Internal pasa SEM-PLS menggunakan nilai composite reliability. Nilai composite reliability yang disarankan adalah $\geq 0,7$, namun nilai reliabilitas 0,6 sudah memenuhi composite reliability.

Dari lima variabel laten atau konstruk yang ada, satu variabel laten yang memiliki nilai composite reliability $\leq 0,7$ yaitu Variabel $\mathrm{Z}$, sehingga Variabel $\mathrm{Z}$ dinyatakan tidak reliabel. 
Tabel 3

Nilai Composite Reliability Variabel Laten

\begin{tabular}{|c|c|c|}
\hline Variabel laten & Composite Reliability & Keterangan \\
\hline Moderating effect 1 & 1,000 & Reliabel \\
\hline Moderating effect 2 & 1,000 & Reliabel \\
\hline
\end{tabular}

Sumber : Pengolahan data dengan perangkat lunak SmartPLS

3) Validitas Konvergen

Dalam memeriksa apakah suatu variabel laten memenuhi validitas konvergen dapat menggunakan nilai Average Variance Extracted (AVE), agar suatu variabel laten dapat dikatakan memenuhi validitas konvergen, nilai AVE harus > 0,5 (Bagozzi \& Yi, 1988:77).

Tabel 4

Nilai Average Variance Extracted (AVE) Variabel Laten

\begin{tabular}{|c|c|c|}
\hline Variabel laten & Average Variance Ectracted $(A V E)$ & Keterangan \\
\hline Moderating effect 1 & 1,000 & Valid \\
\hline Moderating effect 2 & 1,000 & Valid \\
\hline
\end{tabular}

Sumber : Pengolahan data dengan perangkat lunak SmartPLS

Hasil pada tabel 4 menunjukkan bahwa terdapat kedua variabel moderating effect memiliki nilai 1,00 yang lebih besar dari 0 , sehingga dinyatakan valid.

\section{Analisis model struktural}

Untuk memprediksi hubungan antar variabel laten perlu dilakukan evaluasi model struktural (Ghozali dan Latan, 2012). Pengujian struktural dapat digunakan untuk melihat apakah data empiris pada penelitian mendukung hubungan dari hipotesis-hipotesis penelitian (Ghozali dan Fuad, 2008). Hubungan hipotesis pada penelitian dapat dilihat dari hubungan antar variabel eksogen dengan variabel endogen dan variabel endogen dengan variabel endogen lainnya yang digambarkan pada model struktural. Oleh karena itu, dengan melakukan pengujian model struktural maka peneliti dapat melihat apakah berdasarkan data empiris hipotesis penelitian diterima atau ditolak.

1) Variasi Variabel Endogen

Untuk melihat kekuatan prediksi dari model struktural dapat menggunakan nilai $R^{2}$ dari setiap variabel endogen (Ghozali \& Laten, 2012). Nilai $R^{2}$ digunakan untuk mengukur variasi model perubahan variabel eksogen terhadap variabel endogen. Misalnya untuk nilai $\mathrm{R}^{2}$ suatu variabel endogen sebesar 0,7 artinya variasi perubahan endogen yang dapat dijelaskan oleh variabel eksogen adalah $70 \%$, sedangkan $30 \%$ sisanya dijelaskan oleh variabel lain diluar model penelitian yang digunakan. Semakin besar nilai $\mathrm{R}^{2}$, maka semakin baik model prediksi dari model penelitian yang digunakan. Menurut Hair et al (2011:426), nilai $\mathrm{R}^{2}$ sebesar 0,75 menunjukkan model kuat, nilai $\mathrm{R}^{2}$ sebesar 0,5 menunjukkan bahwa model moderatte, sedangkan nilai $\mathrm{R}^{2}$ 0,25 menunjukkan bahwa model lemah.

Tabel 5

Nilai $\mathbf{R}^{2}$ Variabel Laten Penelitian

\begin{tabular}{|c|c|c|}
\hline Variabel laten & Nilai $\mathrm{R}^{2}$ & Keterangan \\
\hline $\mathrm{X} 1$ & - & - \\
\hline $\mathrm{X} 2$ & - & - \\
\hline $\mathrm{X} 3$ & - & - \\
\hline
\end{tabular}




\begin{tabular}{|c|c|c|}
\hline Y1 & 0,201 & Lemah \\
\hline Z1 & - & - \\
\hline
\end{tabular}

Sumber : Pengolahan data dengan perangkat lunak SmartPLS

Nilai $\mathrm{R}^{2}$ sebesar $20,1 \%$ pada variabel endogen $\mathrm{Y}$ memperlihatkan bahwa tiga variabel eksogen pertumbuhan perusahaan, ukuran perusahaan, perencanaan pajak dan GCG lemah dalam menjelaskan 20,1\% variasi dari variabel manajemen laba.

\section{Pengujian Hipotesis}

Pengujian hipotesis penelitian menggunakan analisis signifikansi model struktural dengan Bootstrapping. Perangkat lunak SmartPLS dapat menganalisis signifikasi menggunakan bootstrapping yang dikembangkan oleh Efron pada tahun 1970an untuk mengetahui pengaruh antar variabel. Prosedur bootstrapping melakukan resampling kembali menggunakan seluruh data empiris atau sampel asli (Ghozali dan Latan, 2012). Rekomendasi sampel bootstrapp yang direkomendasikan oleh Hair et al. (2011:428) dan Henseler et al. (2009:315) adalah 5000. Hasil pengujian diperoleh nilai signifikasi yang dapat dilihat pada tabel berikut :

Tabel 6

Hasil Path Coefficients Dengan Bootstrapping

\begin{tabular}{|l|r|r|r|r|r|}
\hline & $\begin{array}{c}\text { Original } \\
\text { Sample } \\
(\mathrm{O})\end{array}$ & $\begin{array}{c}\text { Sample } \\
\text { Mean (M) }\end{array}$ & $\begin{array}{c}\text { Standard Deviation } \\
\text { (STDEV) }\end{array}$ & $\begin{array}{c}\text { T Statistics } \\
(\mid \mathrm{O} / \text { STDEV })\end{array}$ & P Values \\
\hline $\mathrm{X} 1->\mathrm{Y}$ & 0.035 & 0.058 & 0.217 & 0.159 & 0.874 \\
\hline $\mathrm{X} 2->\mathrm{Y}$ & -0.074 & -0.101 & 0.332 & 0.223 & 0.824 \\
\hline $\mathrm{X} 3->\mathrm{Y}$ & 0.450 & 0.391 & 0.269 & 1.671 & 0.095 \\
\hline $\begin{array}{l}\text { Moderating } \\
\text { Effect 1 - Y }\end{array}$ & $-0,051$ & -0.014 & 0.372 & 0.138 & 0.890 \\
\hline $\begin{array}{l}\text { Moderating } \\
\text { Effect 2 - Y }\end{array}$ & 0.166 & 0.006 & 0.267 & 0.622 & 0.535 \\
\hline
\end{tabular}

Sumber : Pengolahan data dengan perangkat lunak SmartPLS

Untuk mengetahui apakah path coefficients dari model struktural signifikan atau tidak, dapat dilihat dari nilai T-Statistics. Untuk tingkat signifikansi sebesar 5\%, path coefficient dinilai signifikan apabila nilai T-Statistics lebih dari 1,96.

\section{Pengujian hipotesis berdasarkan variabel laten}

Menurut (Hair et al, 2011:315) nilai minimal T-Statistics untuk menilai signifikan atau tidaknya hubungan dari variabel laten satu dengan variabel laten lain tergantung dari nilai signifikansi yang digunakan, yaitu :

1. Tingkat signifikan $10 \%$, nilai $T$-Statistics minimal sebesar 1,65

2. Tingkat signifikan 5\%, nilai T-Statistics minimal sebesar 1,96

3. Tingkat signifikan $1 \%$, nilai $T$-Statistics minimal sebesar 2,58

Tabel 7

Uji Hipotesis Model Struktural

\begin{tabular}{|c|c|c|c|c|}
\hline & $\begin{array}{c}\text { Original } \\
\text { Sample }(\mathrm{O})\end{array}$ & $\begin{array}{c}\text { T-Statistics } \\
(|\mathrm{O} / \mathrm{STERR}|)\end{array}$ & Hipotesis & Keterangan \\
\hline $\mathrm{X} 1 \rightarrow \mathrm{Y}$ & 0.035 & 0.159 & $\mathrm{H} 1$ & Ditolak \\
\hline $\mathrm{X} 2 \rightarrow \mathrm{Y}$ & -0.074 & 0.223 & $\mathrm{H} 2$ & Ditolak \\
\hline $\mathrm{X} 3 \rightarrow \mathrm{Y}$ & 0.450 & 1.671 & $\mathrm{H} 3$ & Diterima \\
\hline
\end{tabular}

Sumber : Pengolahan data dengan perangkat lunak SmartPLS v.3.2.9

\section{Analisis SEM-PLS dengan moderasi}

Analisis moderasi untuk mengetahui nilai signifikansi dari kompleksitas tugas 
sebagai variabel moderasi dengan variabel eksogen terhadap variabel endogen. Signifikansi dapat ditentukan melalui t-Statistics yang dihasilkan menggunakan perangkat lunak SmartPLS yakni $t$-Statistics > 1,96

Tabel 8

Uji Hipotesis Efek Moderasi

\begin{tabular}{|c|c|c|c|c|}
\hline & $\begin{array}{c}\text { Original } \\
\text { Sample (O) }\end{array}$ & $\begin{array}{c}\text { T-Statistics } \\
(\mid \mathrm{O} / \text { STERR } \mid)\end{array}$ & Hipotesis & Keterangan \\
\hline $\mathrm{ME1} \rightarrow \mathrm{Y}$ & $-0,051$ & 0,138 & $\mathrm{H} 4$ & Ditolak \\
\hline $\mathrm{ME2} \rightarrow \mathrm{Y}$ & 0,166 & 0,622 & H5 & Ditolak \\
\hline
\end{tabular}

Sumber : Pengolahan data dengan perangkat lunak SmartPLS

\section{Simpulan}

Berdasarkan hasil analisis data dan pembahasan tentang pengaruh pertumbuhan perusahaan, ukuran perusahaan dan perencanaan pajak, yang dimoderasi oleh Good Corporate Governance terhadap manajemen laba yang telah diuraikan pada bab sebelumnya, maka hasil penelitian ini dapat ditarik kesimpulan sebagai berikut:

1. Pertumbuhan perusahaan tidak mempunyai pengaruh signifikan terhadap manajemen laba, dengan perolehan nilai t hitung sebesar 0,159 dengan signifikansi 0,874. Koefisien pertumbuhan perusahaan terhadap manajemen laba sebesar 0,035 menunjukkan bahwa semakin tinggi pertumbuhan perusahaan akan meningkatkan manajemen laba.

2. Ukuran perusahaan tidak mempunyai pengaruh signifikan terhadap manajemen laba, dengan perolehan nilai t hitung sebesar 0,223 dengan signifikansi 0,824. Koefisien ukuran perusahaan terhadap manajemen laba sebesar $-0,074$ menunjukkan bahwa semakin tinggi ukuran perusahaan akan menurunkan manajemen laba.

3. Perencanaan pajak mempunyai pengaruh signifikan terhadap manajemen laba pada taraf signifikansi $10 \%$, dengan perolehan nilai t hitung sebesar 1,671 berarti nilai t statistics sebesar 1,671 > 1,65.Koefisien perencanaan pajak terhadap manajemen laba sebesar 0,450 menunjukkan bahwa semakin tinggi perencanaan pajak akan meningkatkan manajemen laba.

4. Good Corporate Governance tidak memoderasi hubungan ukuran perusahaan terhadap manajemen laba, dengan perolehan nilai t hitung sebesar 0,138 dengan signifikansi 0,890. Koefisien Good Corporate Governance sebesar -0,051 menunjukkan bahwa setiap peningkatan Good Corporate Governance sebesar 1 satuan maka akan menurunkan keeratan hubungan ukuran perusahaan dengan manajemen laba sebesar 0,051 .

\section{Saran}

Setelah melihat hasil analisis dan kesimpulan yang telah penulis kemukakan diatas,maka saran yang dapat penulis sampaikan sebagai berikut :

1. Penelitian selanjutnya sebaiknya menggunakan semua sektor perusahaan yang terdaftar di BEI, sehingga hasil penelitian lebih komprehensif karena bisa menjelaskan perusahaan lain yang tidak masuk kategori manufaktur dalam melakukan manajemen laba.

2. Penelitian selanjutnya dapat menambah faktor-faktor lain di luar penelitian ini sehingga model penelitian yang dibangun dapat lebih mengukur ketepatan variabel yang diduga mempengaruhi adanya manajemen laba. 


\section{Daftar Pustaka}

Achyani, Fatchan dan Susi. 2019. "Pengaruh Perencanaan Pajak Terhadap Manajemen Laba". Jurnal Riset Akuntansi dan Keuangan Indonesia Volume 4 Nomor 1 Edisi April. Universitas Nuhammadiyah Surakarta. p: $77-88$.

Aditama, F dan Anna Purwaningsih. 2014. "Pengaruh Perencanaan Pajak Terhadap Manajemen Laba Pada Perusahaan Nonmanufaktur Yang Terdaftar Di Bursa Efek Indonesia". Jurnal Modus Volume 26 Nomor 1 Edisi Maret. Universitas Atmajaya. Yogyakarta. p:33-50.

Aprina, Desi Nur dan Khairunnisa. 2015. "Pengaruh Ukuran Perusahaan, Profitabilitas, dan Kompensasi Bonus Terhadap Manajemen Laba". e-Proceeding of Management Volume 2 Nomor 3 Edisi Desember. Universitas Telkom. Bandung. p: $3251-3258$.

Bagozzi anda Yi. 1988. "On the Evaluation of Structure Equation Model". Journal of the Academy of Marketing Science Volume 16 Nomor 1 Edisi Januari. p: 74-94.

Dwiarti, Rina dan Anna. 2019. "Pengaruh Profitabilitas, Resiko Keuangan dan Pertumbuhan Perusahaan terhadap Manajemen Laba pada Perusahaan Kosmetik dan Keperluan Rumah Tangga yang Terdaftar di Bursa Efek Indonesia Tahun 2013-2017’. Jurnal Manajemen dan Keuangan Volume 8 Nomor 1 Edisi Mei. Universitas Samudra. Aceh. p: $21-33$.

Fricilia dan Hendro. 2015. "Analisis Faktor-Faktor yang Mempengaruhi Praktik Manajemen Laba pada Industri Perbankan di Indonesia". Jurnal Akuntansi Volume 19 Nomor 1 Edisi Januari. Universitas Tarumanegara. p:79 - 92.

Ghozali, I., dan Latan, H. (2012). Partial Least Squares, Konsep, Teknik, dan Aplikasi SmartPLS 2.0 M3. Semarang: Badan Penerbit Universitas Diponegoro.

Gustina dan Lince Bulutoding. 2017. "Pengaruh Penerapan PSAK 55 (Revisi 2011) terhadap Manajemen Laba dengan Ukuran KAP sebagai Variabel Moderating. Jurnal Assets". Volume 7 Nomor 2 Edisi Desember. Fakultas Ekonomi dan Bisnis Islam UIN Alauddin. Makassar. p: 197 - 211.

Hair, Joe et al. 2011. "An Assessment of the Use of Partial Least Squares Structural Euation Modelling in Marketing Research". Academy of Marketing Science Volume 12 Nomor 1 Edisi Juli. p: 414-433.

Henseler, Jorg et al. 2009. The Use of Partial Least Squares Path Modelling in International Marketing. Advances in International Marketing. Emerald. p: 277319.

Khotimah. 2014. "Pengaruh Perencanaan Pajak Terhadap Manajemen Laba". Jurnal Bisnis dan Manajemen Volume 4 Nomor 2 Edisi Agustus. Universitas Islam Negeri Syarif Hidayatullah. Jakarta. p: 170 - 177.

Kusumawati. Eny. 2019. "Determinan Manajemen Laba: Kajian Empiris pada Perusahaan Manufaktur Go Publik di Bursa Efek Indonesia". Jurnal Riset Akuntansi dan Keuangan Indonesia. Volume 4 Nomor 1 Edisi April. Universitas Muhammadiyah Surakarta. p: 25 - 42.

Lestari dan Sugeng. 2013. "Pengaruh Earnings Management Terhadap Nilai Perusahaan Dimoderasi Dengan Praktik Good Corporate Governance (Studi Empiris Pada Perusahaan Non Keuangan yang Terdaftar di Bursa Efek Indonesia” Tahun 2008 2011). Diponegoro Journal of Accounting Volume 2 Nomor 3 Edisi Juli. Universitas Diponegoro. p: 494 - 502. 
Makaombohe, Yuliati Yosephani, Sifrid S., dan Victorina. 2014. "Ukuran Perusahaan Terhadap Manajemen Laba Pada Perbankan yang Terdaftar di Bursa Efek Indonesia Periode 2008-2011”. Jurnal EMBA Volume 2, Nomor 1 Edisi Maret. Universitas Sam Ratulangi. Manado. p: $656-665$.

Pertiwi, Tri Kartika dan Ferry. 2011. "Pengaruh Kinerja Keuangan, Good Corporate Governance terhadap Nilai Perusahaan Food And Beverage". Jurnal Manajemen dan Kewirausahaan Volume 14 Nomor 2 Edisi September. Universitas Kristen Petra. Surabaya. p: 118-127.

Scott, W. R. 2011. Financial Accounting Theory, 6 edition. United States: Pearson.

Siagian, Sondang P. 2011. Manajemen Sumberdaya Manusia. Jakarta. Bumi Aksara.

Suandy, Erly. 2014. Perencanaan Pajak. Salemba Empat: Jakarta

Swingly, Calvin dan I. M. Sukartha. 2015. "Pengaruh Karakter Eksekutif, Komite Audit, Ukuran Perusahaan, Leverage dan Sales Growth pada Tax Avoidance". EJurnal Akuntansi. Volume 10 Nomor 1 Edisi Januari. Universitas Udayana. p: $47-62$.

Wibisana, Imas Danar dan Ratnaningsih. 2014. "Analisis Faktor-Faktor yang Mempengaruhi Arah Manajemen Laba (Studi Pada Perusahaan Manufaktur yang Terdaftar di BEI 2009-2013)”. Jurnal Ekonomi Akuntansi. Universitas Atma Jaya. Yogyakarta. p: $1-13$.

Yudiastuti dan I Wayan. 2018. "Good Corporate Governance Memoderasi Pengaruh Leverage Terhadap Manajemen Laba". e-journal Akuntansi Volume 23 Nomor 1 Edisi April. Universitas Udayana. Bali. p: 130 - 155. 
